\title{
Assessment of attitude and perception of medical students towards rural health services in hilly region of Uttarakhand
}

\author{
Dheeraj Gupta ${ }^{1}$, Shiv Kumar Yadav ${ }^{2}$, A R Piyush ${ }^{3}$, Nidhi Mimani Gupta ${ }^{4}$, Bhola Nath ${ }^{5}$ \\ ${ }^{1}$ Associate Professor, ${ }^{2,3}$ Assistant Professor, ${ }^{4}$ Consultant, ${ }^{5}$ Professor, ${ }^{1,2,5}$ Dept. of Community Medicine, ${ }^{3}$ Dept. of Pathology, ${ }^{4}$ Dept. of \\ Dermatology, ${ }^{1-3,5}$ Govt. Doon Medical College, Dehradun, Uttrakhand, India
}

*Corresponding Author: Shiv Kumar Yadav

Email: dr.skynet85@gmail.com

\begin{abstract}
Introduction: There is acute shortage of efficient health care providers especially doctors in rural areas of our country. As per Census 2011 approximately $70 \%$ of Indian population resides in rural areas and hence possess a major challenge for the government as well policy makers to ensure availability of doctors in peripheral health post situated in rural and hard to reach areas of country.

Objective: To explore the Attitude and Perception of medical students towards rural health services in hilly region of Uttrakhand.

Material and Methods: A descriptive cross-sectional study was conducted among $282 \mathrm{MBBS}$ students of $1^{\text {st }}, 3^{\text {rd }}$ and $5^{\text {th }}$ Semesters of Government Medical College of Uttarakhand. A predesigned, pretested, self-administered questionnaire was administered to the participants for data collection. Data was entered and analysed with SPSS software.

Result: Among 282 MBBS Students, 64\% showed interest to work in rural area. $68 \%$ females showed willingness to work in rural area compared to $57.6 \%$ of males and $78.9 \%$ study Participants belonging to rural areas showed interest to join rural health services compared to $57.8 \%$ belonging to urban area. Reasons identified for non-willingness to work in rural areas were less salary (73\%), limited infrastructures in health facilities (92.6\%), Delay in Post-Graduation (85.8\%), limited scope of professional growth (85.1\%), lack of educational opportunities for children and family amenities $(84.4 \%)$, lack of recreational facilities in rural area $(71.6 \%)$ and remote location areas $(77.7 \%)$ and less opportunity to interact with colleagues of medical field $(69.1 \%)$.

Conclusion: Medical student's attitude and perception to work in rural health services need much improvement towards positive side by intervention and implementation by joint collaborative efforts of Medical Education Department, Health department and State Government.
\end{abstract}

Keywords: Rural health services, Medical students, Perception.

\section{Introduction}

There is acute shortage of doctors in health care facilities in rural India. As per Census 2011, approximately $70 \%$ of population is residing in rural areas of India, ${ }^{1}$ so efficient and timely health care facilities and health care providers (Doctors) availability for rural areas is utmost importance for the country progress. Recent reports documented that the country has a doctor population ratio of 1:1800 compared to the World Health Organization norm of $1: 1000 .^{2}$ The distribution of doctors showed significant preference towards urban side. 40,000 allopathic doctors are produced every year in India, ${ }^{3}$ but only a minimal number shows preference to practice in rural areas. There is deficiency of doctors in $18 \%$ of primary health centres (PHCs) and $54 \%$ of community health centres in the country, ${ }^{4}$ which reflects that there is acute shortage of qualified medical doctors who are willing to serve in rural India. Globally the scenario is same in many countries like Malaysia, Nepal, Uganda and other developing countries. ${ }^{5,6}$

Doctors prefer to work in urban areas due to higher incomes, better living conditions and better educational opportunities for their children's and not willing to work in rural area due to poor living standards for the family, lack of financial progress, less opportunities for skill up gradation, and less professional development. ${ }^{7}$

To cater to this deficit in the health system, Medical Council of India with health ministry is planning a separate medical graduate course to the students belonging to rural background to cater the needs of rural population. ${ }^{8}$ Compulsory rural clinical placement for medical students has also been suggested as one strategy to sensitize future health professionals with the rural workplace. ${ }^{2}$ This Study was planned to identify the attitudes and perception of medical students towards rural health services and innovating strategies to increase the quality and quantity of doctors available to the deprived rural population of the nation.

\section{Objective}

1. To explore the perception among medical students about their willingness to work in Rural Health Services of Uttarakhand.

2. To find out the factors responsible for Non- Willingness to work in rural Health service of Uttarakhand

3. To Document the various interventions by which perception and preferences towards Rural Health services can be improved.

\section{Materials and Methods}

A descriptive cross-sectional study carried among 282 MBBS students studying in $1^{\text {st }}, 3^{\text {rd }}$ and $5^{\text {th }}$ semesters of Government Medical College, Uttarakhand. Participants were enrolled by convenient sampling method. Data collection was carried out for a period of 3 months (Oct-Dec 2018). Medical Students were explained the purpose of study, and written informed consent was obtained from each participant before the questionnaire was administered. The confidentiality of all participants was maintained and each participant was assigned unique ID. Data tool used was predesigned, pretested, self-administered questionnaire. 
Data was entered and analysed with SPSS software version 22. Means $( \pm \mathrm{SD})$ was computed for continuous variables and percentages for categorical variables. Chi square, Student $\mathrm{t}$ test were used to look for significant association. Individual componentwise analyses were done using tables with percentages. The study was approved by the Institutional Ethics Committee.

\section{Results}

Table 1 shows majority of Students (164/282) were in the age group of 20-22 years and out of them $64.0 \%$ showed interest to work in rural area. Among Participants, 68\% Females showed willingness to work in rural area compared to $57.6 \%$ of Males. $69.3 \%$ first Semester Medical Students were inclined towards service in rural area as compared to Third (62.5\%) and Fifth Semester Students (55.9\%). About four-fifth of study Participants belonging to rural areas showed interest to join rural Health services compared to three-fifth belonging to Urban Area. There was significant difference in willingness and place of residence among medical students ( $p$ Value - 0.002). Place of schooling also has a significant impact on student's interest towards rural health services as those who has taken Schooling from rural area $(77.8 \%)$ were more inclined and willing to serve as compared to those who have taken schooling from urban areas $(60.3 \%)$. About two-third of medical students who have opted for rural health service bond during admission were willing to work in rural areas as compared to $28.6 \%$ of those who have not opted for it and there was significant difference in the opinion among participants ( $p$ Value $<0.05)$.

Father occupation, education, place of work and total family income do not have any significant association towards willingness of medical students to work in rural area. Mother Education proved to be a significant factor in decision making and willingness of students towards rural health service ( $\mathrm{p}$ value - 0.00008) although mother occupation did not contributed as majority of them were housewife $(75.2 \%)$ [Table 2].

Graph 1: Comparative representation of willing to Work and Opting Bond for rural health services.

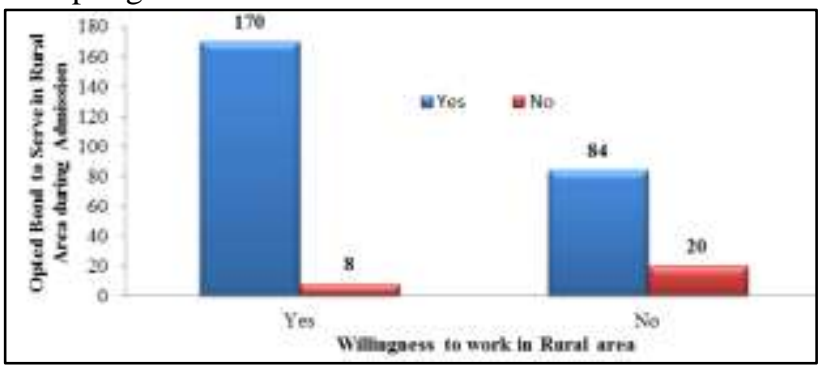

Out of $254(90.1 \%)$ Students who opted for Bond (Compulsory rural Health service for minimum Three years after MBBS Completion) only $170(66.9 \%)$ were willing to serve in rural area as shown in graph 1.

Table 1: Association of Factors with willingness to serve in rural health services

\begin{tabular}{|c|c|c|c|c|c|c|}
\hline \multirow[t]{2}{*}{ S. No } & \multirow[t]{2}{*}{ Variables } & \multirow[t]{2}{*}{ Categories } & \multirow[t]{2}{*}{$\begin{array}{c}\text { Values }(\mathbf{n}=\mathbf{2 8 2}) \\
\mathbf{N}(\%)\end{array}$} & \multicolumn{2}{|c|}{$\begin{array}{l}\text { Willingness to work in } \\
\text { Rural Area }(n=282)\end{array}$} & \multirow[t]{2}{*}{$\begin{array}{c}\text { Chi-Square } \\
\text { (p Value) }\end{array}$} \\
\hline & & & & Yes N (\%) & No N (\%) & \\
\hline \multirow[t]{3}{*}{1} & \multirow{3}{*}{ Age } & 17-19 Years & $108(38.3)$ & $65(60.0)$ & $43(40.0)$ & \multirow{3}{*}{$\begin{array}{c}1.681 \\
(0.431)\end{array}$} \\
\hline & & 20-22 Years & $164(58.2)$ & $105(64.0)$ & $59(36.0)$ & \\
\hline & & $\geq 23$ Years & $10(3.5)$ & $08(80.0)$ & $02(20.0)$ & \\
\hline \multirow[t]{2}{*}{2} & \multirow{2}{*}{ Gender } & Male & $132(46.8)$ & $76(57.6)$ & $56(42.4)$ & \multirow{2}{*}{$\begin{array}{c}3.728 \\
(0.083)\end{array}$} \\
\hline & & Female & $150(53.2)$ & $102(68.0)$ & $48(32.0)$ & \\
\hline \multirow[t]{3}{*}{3} & \multirow[t]{3}{*}{ Semester } & First & $124(4.4)$ & $86(69.3)$ & $38(30.7)$ & \multirow{3}{*}{$\begin{array}{c}4.37 \\
(0.112)\end{array}$} \\
\hline & & Third & $56(19.9)$ & $35(62.5)$ & $21(37.5)$ & \\
\hline & & Fifth & $102(36.1)$ & $57(55.9)$ & $45(44.1)$ & \\
\hline \multirow[b]{2}{*}{4} & \multirow{2}{*}{ Residence } & Rural & $71(25.2)$ & $56(78.9)$ & $15(21.1)$ & \multirow{2}{*}{$\begin{array}{l}10.115 \\
(0.002)\end{array}$} \\
\hline & & Urban & $211(74.8)$ & $122(57.8)$ & $89(42.2)$ & \\
\hline \multirow{2}{*}{5} & \multirow{2}{*}{ School } & Rural & $45(16.0)$ & $35(77.8)$ & $10(22.2)$ & \multirow{2}{*}{$\begin{array}{c}4.94 \\
(0.02)\end{array}$} \\
\hline & & Urban & $237(84.0)$ & $143(60.3)$ & $94(39.7)$ & \\
\hline \multirow[b]{2}{*}{6} & \multirow{2}{*}{ Admission Quota } & State & $276(97.9)$ & $175(63.4)$ & $101(36.6)$ & \multirow{2}{*}{$\begin{array}{c}0.453 \\
(0.673)\end{array}$} \\
\hline & & All India & $06(2.1)$ & $03(50.0)$ & $03(50.0)$ & \\
\hline \multirow{2}{*}{7} & \multirow{2}{*}{$\begin{array}{l}\text { Decision to join } \\
\text { Medical profession }\end{array}$} & Self & $240(85.1)$ & $154(64.2)$ & $86(35.8)$ & \multirow{2}{*}{$\begin{array}{c}0.758 \\
(0.383)\end{array}$} \\
\hline & & Parents & $42(14.9)$ & $24(57.1)$ & $18(42.9)$ & \\
\hline \multirow[b]{2}{*}{8} & \multirow{2}{*}{$\begin{array}{l}\text { Opted Bond to Serve in } \\
\text { Rural Area during } \\
\text { Admission }\end{array}$} & Yes & $254(90.1)$ & $170(66.9)$ & $84(33.1)$ & \multirow{2}{*}{$\begin{array}{c}15.94 \\
(<0.001)\end{array}$} \\
\hline & & No & $28(9.9)$ & 08 (28.6) & $20(71.4)$ & \\
\hline
\end{tabular}


Table 2: Association of Factors with willingness to serve in rural health services

\begin{tabular}{|c|c|c|c|c|c|c|}
\hline \multirow[t]{2}{*}{ S. No } & \multirow[t]{2}{*}{ Variables } & \multirow[t]{2}{*}{ Categories } & \multirow[t]{2}{*}{$\begin{array}{c}\text { Values } \\
(\mathbf{n}=\mathbf{2 8 2}) \mathbf{N}(\%)\end{array}$} & \multicolumn{2}{|c|}{$\begin{array}{l}\text { Willingness to work in } \\
\text { Rural Area }(\mathbf{n}=\mathbf{2 8 2})\end{array}$} & \multirow[t]{2}{*}{$\begin{array}{l}\text { Chi-Square } \\
\text { (p Value) }\end{array}$} \\
\hline & & & & Yes n $(\%)$ & No $N(\%)$ & \\
\hline \multirow[t]{5}{*}{1} & \multirow[t]{5}{*}{ Father Education } & $\leq$ Middle school & $12(4.2)$ & $09(75.0)$ & $3(25)$ & \multirow{5}{*}{$\begin{array}{c}3.886 \\
(0.4216)\end{array}$} \\
\hline & & High school & $11(3.9)$ & $09(81.8)$ & $2(18.2)$ & \\
\hline & & Intermediate & $42(14.9)$ & $29(69.1)$ & $13(30.9)$ & \\
\hline & & Graduate & $120(42.6)$ & $71(59.2)$ & $49(40.8)$ & \\
\hline & & Post Graduate & $97(34.4)$ & $60(61.9)$ & $37(38.1)$ & \\
\hline \multirow[t]{5}{*}{2} & \multirow{5}{*}{$\begin{array}{l}\text { Mother } \\
\text { Education }\end{array}$} & $\leq$ Middle school & $31(11.0)$ & $26(83.9)$ & $5(16.1)$ & \multirow{5}{*}{$\begin{array}{c}23.94 \\
(0.00008)\end{array}$} \\
\hline & & High school & $23(8.2)$ & $19(82.6)$ & $4(17.4)$ & \\
\hline & & Intermediate & $51(18.1)$ & $37(72.5)$ & $14(27.5)$ & \\
\hline & & Graduate & $90(31.9)$ & $57(63.3)$ & $33(36.7)$ & \\
\hline & & Post Graduate & $87(30.8)$ & $39(44.8)$ & $48(55.2)$ & \\
\hline \multirow[t]{8}{*}{3} & \multirow{8}{*}{$\begin{array}{c}\text { Father } \\
\text { Occupation }\end{array}$} & Unemployed & $07(2.5)$ & $04(57.1)$ & $3(42.9)$ & \multirow{8}{*}{$\begin{array}{c}\text { Yates } \\
\text { Corrected Chi } \\
\text { Square- } 6.128 \\
(0.524)\end{array}$} \\
\hline & & Elementary Worker & $01(0.3)$ & $01(100.0)$ & $00(0.0)$ & \\
\hline & & Craftsman & $06(2.1)$ & $04(66.7)$ & $2(33.3)$ & \\
\hline & & Skilled Agriculture & $33(11.7)$ & $26(78.8)$ & $7(21.2)$ & \\
\hline & & $\begin{array}{c}\text { Skilled } \\
\text { work/Shopkeeper }\end{array}$ & 49 (17.4) & $35(71.4)$ & $14(28.6)$ & \\
\hline & & Clerk/Technicians & $127(45.0)$ & $73(57.5)$ & $54(42.5)$ & \\
\hline & & Businessman & $49(17.5)$ & $28(57.1)$ & $21(42.9)$ & \\
\hline & & Professional & $10(3.5)$ & $07(70.0)$ & $3(30)$ & \\
\hline \multirow[t]{6}{*}{4} & \multirow{6}{*}{$\begin{array}{c}\text { Mother } \\
\text { Occupation }\end{array}$} & Housewife & $212(75.2)$ & $139(65.6)$ & $73(34.4)$ & \multirow{6}{*}{$\begin{array}{c}\text { Yates } \\
\text { Corrected Chi } \\
\text { Square- } 5.406 \\
(0.368)\end{array}$} \\
\hline & & Skilled Agriculture & $01(0.3)$ & $01(100.0)$ & $0(0)$ & \\
\hline & & $\begin{array}{c}\text { Skilled } \\
\text { work/Shopkeeper }\end{array}$ & $04(1.4)$ & $03(75.0)$ & $01(25.0)$ & \\
\hline & & Clerk /Technicians & $22(7.8)$ & $14(63.6)$ & $08(36.4)$ & \\
\hline & & Businessman & $38(13.5)$ & $17(44.7)$ & $21(55.3)$ & \\
\hline & & Professional & $05(1.8)$ & $04(80.0)$ & $01(20.0)$ & \\
\hline \multirow[t]{2}{*}{5} & \multirow{2}{*}{$\begin{array}{c}\text { Parents Working } \\
\text { Place }\end{array}$} & Urban & $201(71.3)$ & $122(60.7)$ & $79(39.3)$ & \multirow{2}{*}{$\begin{array}{l}1.776 \\
(0.220)\end{array}$} \\
\hline & & Rural & $81(28.7)$ & $56(69.1)$ & $25(30.9)$ & \\
\hline \multirow[t]{4}{*}{6} & \multirow{4}{*}{$\begin{array}{c}\text { Total family } \\
\text { Income monthly }\end{array}$} & $\leq 10,000$ & $17(6.0)$ & $11(64.7)$ & $06(35.3)$ & \multirow{4}{*}{$\begin{array}{c}3.44 \\
(0.327)\end{array}$} \\
\hline & & $10000-50000$ & $153(54.3)$ & $103(67.3)$ & $50(32.7)$ & \\
\hline & & 50000-1lac & $80(28.4)$ & $44(55.0)$ & $36(45.0)$ & \\
\hline & & More than 1 lac & $32(11.3)$ & $20(62.5)$ & $12(37.5)$ & \\
\hline
\end{tabular}

Table 3: Reasons for willingness to work in rural areas of Uttarakhand

\begin{tabular}{|c|l|c|c|c|c|c|}
\hline $\begin{array}{c}\text { S. } \\
\text { No }\end{array}$ & \multicolumn{1}{|c|}{ Variables } & $\begin{array}{c}\text { Strongly } \\
\text { agree N(\%) }\end{array}$ & $\begin{array}{c}\text { Agree } \\
\mathbf{N}(\%)\end{array}$ & $\begin{array}{c}\text { Neutral } \\
\mathbf{N}(\%)\end{array}$ & $\begin{array}{c}\text { Disagree } \\
\mathbf{N}(\%)\end{array}$ & $\begin{array}{c}\text { Strongly } \\
\text { Disagree N (\%) }\end{array}$ \\
\hline 1 & $\begin{array}{l}\text { I will do private practice and earn more } \\
\text { money in rural area }\end{array}$ & $08(2.8)$ & $21(7.4)$ & $100(35.5)$ & $109(38.7)$ & $44(15.6)$ \\
\hline 2 & $\begin{array}{l}\text { To join government health facility and } \\
\text { secure my job }\end{array}$ & $60(21.3)$ & $133(47.2)$ & $66(23.4)$ & $18(6.4)$ & $05(1.8)$ \\
\hline 3 & $\begin{array}{l}\text { Own residence in rural areas so will } \\
\text { settle there. }\end{array}$ & $08(2.8)$ & $22(7.8)$ & $72(25.5)$ & $125(44.3)$ & $55(19.5)$ \\
\hline 4 & $\begin{array}{l}\text { To contribute for betterment of health } \\
\text { system of state }\end{array}$ & $126(44.7)$ & $130(46.1)$ & $23(8.2)$ & $01(0.4)$ & $02(0.7)$ \\
\hline 5 & $\begin{array}{l}\text { I have opted for Compulsory government } \\
\text { service/bond }\end{array}$ & $90(31.9)$ & $130(46.1)$ & $31(11.0)$ & $15(5.3)$ & $16(5.7)$ \\
\hline 6 & $\begin{array}{l}\text { It will Provides an opportunity for } \\
\text { independent working }\end{array}$ & $33(11.7)$ & $106(37.6)$ & $87(30.9)$ & $46(16.3)$ & $10(3.5)$ \\
\hline 7 & $\begin{array}{l}\text { It will Provides an good exposure of } \\
\text { general practice }\end{array}$ & $51(18.1)$ & $111(39.4)$ & $50(17.7)$ & $54(19.1)$ & $16(5.7)$ \\
\hline 8 & $\begin{array}{l}\text { It will helps to build confidence as a } \\
\text { clinician }\end{array}$ & $60(21.3)$ & $130(46.1)$ & $58(20.6)$ & $25(8.8)$ & $09(3.2)$ \\
\hline
\end{tabular}




\begin{tabular}{|c|l|c|c|c|c|c|}
\hline 9 & $\begin{array}{l}\text { Working in rural area gives more job } \\
\text { satisfaction }\end{array}$ & $26(9.2)$ & $55(19.5)$ & $94(33.3)$ & $75(26.6)$ & $32(11.3)$ \\
\hline 10 & $\begin{array}{l}\text { Working in rural area helps in earning } \\
\text { more money }\end{array}$ & $08(2.8)$ & $06(2.1)$ & $62(22.0)$ & $144(51.1)$ & $62(22.0)$ \\
\hline 11 & People in rural areas are more supportive & $45(16.0)$ & $113(40.1)$ & $92(32.6)$ & $22(7.8)$ & $10(3.5)$ \\
\hline
\end{tabular}

Table 4: Reasons for Non-willingness to work in rural areas of Uttarakhand

\begin{tabular}{|c|c|c|c|c|c|c|}
\hline S. No & Variables & $\begin{array}{c}\text { Strongly } \\
\text { agree } \mathbf{N}(\%)\end{array}$ & $\begin{array}{l}\text { Agree } \\
\mathbf{N}(\%)\end{array}$ & $\begin{array}{c}\text { Neutral } \\
\mathbf{N}(\%)\end{array}$ & $\begin{array}{c}\text { Disagree } \\
\mathrm{N}(\%)\end{array}$ & $\begin{array}{c}\text { Strongly } \\
\text { Disagree N(\%) }\end{array}$ \\
\hline 1 & Limited infrastructures in health facilities & $119(42.2)$ & $142(50.4)$ & $18(6.4)$ & $02(0.7)$ & $01(0.4)$ \\
\hline 2 & Delay in PG & $145(51.4)$ & $97(34.4)$ & $27(9.6)$ & $10(3.5)$ & $03(1.1)$ \\
\hline 3 & Limited Professional growth & $105(37.2)$ & $135(47.9)$ & $27(9.6)$ & $13(4.6)$ & $02(0.7)$ \\
\hline 4 & $\begin{array}{l}\text { own residence in urban area so will not go } \\
\text { in rural area }\end{array}$ & 45 (16.0) & $74(26.2)$ & $89(31.6)$ & $65(23.0)$ & $09(3.2)$ \\
\hline 5 & $\begin{array}{l}\text { lack of educational opportunities of children } \\
\text { and family amenities }\end{array}$ & $118(41.8)$ & $120(42.6)$ & $30(10.6)$ & 11(3.9) & $03(1.1)$ \\
\hline 6 & Less salary & $60(21.3)$ & $86(30.5)$ & $97(34.4)$ & $37(13.1)$ & $02(0.7)$ \\
\hline 7 & $\begin{array}{l}\text { Provides lesser opportunities to upgrade } \\
\text { knowledge and skills }\end{array}$ & $106(37.6)$ & $125(44.3)$ & $30(10.6)$ & $21(7.4)$ & $00(0.0)$ \\
\hline 8 & $\begin{array}{l}\text { Difficulty in pursuing post-graduation after } \\
\text { working in rural areas for a considerable } \\
\text { time }\end{array}$ & $120(42.6)$ & $105(37.2)$ & $32(11.3)$ & $23(8.2)$ & $02(0.7)$ \\
\hline 9 & lack of recreational facilities & $74(26.2)$ & $128(45.4)$ & $47(16.7)$ & $31(11.0)$ & $02(0.7)$ \\
\hline 10 & $\begin{array}{l}\text { Remote geographical location of health } \\
\text { posts }\end{array}$ & $97(34.4)$ & $122(43.3)$ & $49(17.4)$ & $12(4.3)$ & $020.7)$ \\
\hline 11 & $\begin{array}{l}\text { It is frustrating if unable to pursue post- } \\
\text { graduation }\end{array}$ & $121(42.9)$ & $103(36.5)$ & $38(13.5)$ & $20(7.1)$ & $00(0.0)$ \\
\hline 12 & Connectivity with cities is not good & $85(30.1)$ & $133(47.2)$ & $41(14.5)$ & $20(7.1)$ & $03(1.1)$ \\
\hline 13 & Isolation from family and relatives & $108(38.3)$ & $89(31.6)$ & $55(19.5)$ & $29(10.3)$ & $01(0.4)$ \\
\hline 14 & $\begin{array}{l}\text { Provides lesser opportunities for interaction } \\
\text { with colleagues of medical field. }\end{array}$ & $90(31.9)$ & $105(37.2)$ & $64(22.7)$ & $19(16.7)$ & $04(1.4)$ \\
\hline
\end{tabular}

Table 5: How can we improve Rural health services

\begin{tabular}{|c|l|c|c|c|c|c|}
\hline S. No & \multicolumn{1}{|c|}{ Variables } & $\begin{array}{l}\text { Strongly } \\
\text { agree }\end{array}$ & Agree & Neutral & Disagree & $\begin{array}{l}\text { Strongly } \\
\text { Disagree }\end{array}$ \\
\hline 1 & $\begin{array}{l}\text { Salary and incentives should be regular and } \\
1.5 \text { times of current salary }\end{array}$ & $146(51.8)$ & $107(37.9)$ & $25(8.9)$ & $02(0.7)$ & $02(0.7)$ \\
\hline 2 & $\begin{array}{l}\text { Reservation in PG seat for services in rural } \\
\text { area }\end{array}$ & $141(50.0)$ & $90(31.9)$ & $27(9.6)$ & $14(5.0)$ & $10(3.5)$ \\
\hline 3 & Improvement in Hospital infrastructure & $204(72.3)$ & $70(24.8)$ & $06(2.1)$ & $01(0.4)$ & $01(0.4)$ \\
\hline 4 & Improvement in Residential facilities & $172(61.0)$ & $96(34.0)$ & $11(3.9)$ & $02(0.7)$ & $01(0.4)$ \\
\hline 5 & $\begin{array}{l}\text { Decreases duration of posting in Rural } \\
\text { Health services to 2 years }\end{array}$ & $182(64.5)$ & $53(18.8)$ & $33(11.7)$ & $10(3.5)$ & $04(1.4)$ \\
\hline 6 & $\begin{array}{l}\text { Must be compulsory after MBBS for every } \\
\text { Indian Medical Graduate }\end{array}$ & $113(40.1)$ & $71(25.2)$ & $47(16.7)$ & $29(10.3)$ & $22(7.8)$ \\
\hline 7 & $\begin{array}{l}\text { Must be compulsory after MBBS only for } \\
\text { Indian Medical Graduate who are bonded. }\end{array}$ & $38(13.5)$ & $68(24.1)$ & $58(20.6)$ & $66(23.4)$ & $52(18.4)$ \\
\hline
\end{tabular}

In Table 3, Reasons for willingness to work in rural areas of Uttarakhand among medical students were explored and it was found that job security linked with rural govt. health facility was the reason among $68.5 \%$ students, $90.5 \%$ want to contribute to better health of the state, $57.5 \%$ believed that it will provide good exposure for general practice, $67.4 \%$ believed it will build confidence as clinician and $56.1 \%$ believed people in rural area are more supportive.

Reasons for Non-willingness to work in rural areas of Uttarakhand by Medical students is shown in Table 4 and it was found that $92.6 \%$ of them believed that Limited infrastructures in health facilities, $85.8 \%$ perceives that Rural services leads to Delay in Post-Graduation and $85.1 \%$ expressed there is limited scope of professional growth after entering rural health services. Medical Students (84.4\%) expressed that lack of educational opportunities for children and family amenities hinders them to opt for rural health services. Less Salary being paid during rural health services was also considered an issue among medical students. 
$81.9 \%$ of medical students believes that Rural health services Provides lesser opportunities to upgrade knowledge and skills, $79.8 \%$ expressed that there is difficulty in pursuing post-graduation after working in rural areas for a considerable time, $71.6 \%$ also mentioned that there is lack of recreational facilities in rural area and $77.7 \%$ also pointed out that health post in rural area are located in remote areas and connectivity with cities is not good and they feel isolated from family. $69.1 \%$ of medical students are of the opinion that service in rural area gives less opportunity to interact with colleagues of medical field (table 4).

Table 5 shows the students perception related to methods by which Rural Health Services could be improved. It was found that $89.7 \%$ of the participants believed that salary should be increased to 1.5 times of current salary and regular salary should be dispensed. $81.9 \%$ expressed that there should be reservation in PG seats for those serving in rural area. $97.1 \%$ believed that Rural Hospital Infrastructure should be improved, 95\% also expressed that residential facilities for doctors in hospital premises should be improved. $83.3 \%$ of the subjects think that duration of posting to rural health services should be reduced to 2 years and $65.3 \%$ medical students mentioned that rural health services should be made compulsory to all Indian medical graduates to improve rural health services in India.

\section{Discussion}

Availability of adequate, trained health workforce, especially trained doctors for rural healthcare services is an utmost need for India. A study done by Rao et $\mathrm{al}^{9}$ elicited that rural health services are severely constrained due to acute shortage of health workers particularly Doctors. In this study $63.1 \%$ Medical students were willing to serve which is more than the finding of similar study done by Saini $\mathrm{NK}^{10}$ where $54.7 \%$ of the students were willing to serve in rural area for some time after graduation. Study done by Jain M showed that nearly $44 \%$ students were willing to serve in the rural area. ${ }^{11}$

In the present study, attitude of students were compared with their residential background in the present study and it was found that $78.9 \%$ students belonging to rural areas showed interest to join rural Health Services compared to $57.8 \%$ belonging to Urban Area. There was significant difference in willingness and place of residence among medical students ( $p$ Value-0.002). These findings are similar to findings by Saini $\mathrm{NK}^{10}$ which showed that ruralbackground students were more likely to practice in rural areas.

Factors expressed by students which promotes them to work in Rural health service of Uttarakhand were job security $(68.5 \%)$, willingness to contribute to better health of the state $(90.5 \%)$, good exposure for general practice $(57.5 \%)$, building confidence as clinician $(67.4 \%)$. Similar finding were elicited by studies done by Saini $\mathrm{NK}^{10}$, Chudhary $\mathrm{Y}^{12}$ and Ossai $\mathrm{E}^{13}$. In current study, $83.3 \%$ expressed that duration of posting to rural health services should be reduced to 2 years which was also seen in Ugandan study. ${ }^{14}$

In our study, $65.3 \%$ medical students mentioned that rural health services should be made compulsory to all Indian medical graduates to improve rural health services in India which is similarly reported by Curran VR. ${ }^{15}$

Among study participants, reasons for non-willingness to work in rural areas of Uttrakhand were money earned in rural area is less compared to urban area $(73.1 \%)$ and limited infrastructures in health facilities $(92.6 \%)$, rural services leads to delay in Post-Graduation $(85.8 \%)$ and limited scope of professional growth after entering rural health services $(85.1 \%)$, lack of educational opportunities for children and family amenities (84.4\%), lesser opportunities to upgrade knowledge and skills (81.9\%), difficulty in pursuing post-graduation after working in rural areas for a considerable time $(79.8 \%)$, lack of recreational facilities in rural area $(71.6 \%)$ and remote location areas (77.7\%) and less opportunity to interact with colleagues of medical field $(69.1 \%)$. Similar findings were supported by studies of Saini $\mathrm{NK}^{10}$ in NCR India region, Jain $\mathrm{M}^{11}$ in Chhattisgarh region and other similar studies conducted in various region of the world. ${ }^{16-18}$

In this study, students perception by which Rural Health Services could be improved were salary should be increased to 1.5 times compared to urban area and regular salary should be dispensed, reservation in PG seats for those serving in rural area, Rural Hospital Infrastructure, residential facilities for doctors in hospital premises. These finding were comparable to various studies which suggested that attractive financial incentives can address doctors shortages in rural areas. ${ }^{19,20}$ up-gradation of facilities at rural health post like 24 hour ambulance services, better transport, better housing and sanitation, better food facilities, availability of basic medicines and diagnostic facilities, better infrastructure, and working conditions can improve the shortage of doctors in the Rural health facilities. $^{10}$

\section{Conclusion}

Medical students willingness and attitude towards working in Rural Health services is still lack positivity and perceived barriers still exists which are less salary, No Infrastructure in Health facilities, Lack of Facilities for the doctor's family, Delay in Post-Graduation, Decline in Clinical Skills during Rural Health Practices are well known factors known to policy makers. Some States have implemented policies to improve but still the deficit of doctors opting for rural health service is persisting. A careful analysis of the situation is required to find medium to long-term solutions for this problem. This would require to deeply introspecting at the pre-existing health policies and adapting them accordingly to retain the services of doctors in rural India.

\section{Limitations}

The study data involves attitude and perception of medical students of only one state and therefore cannot be generalised. Another limitation being a cross-sectional 
study, the future change of behaviour or behaviour persistence cannot be elicited now. Most of the medical students in the study had little exposure to rural areas, which limited their ability to perceive rural health services and its characteristics.

\section{Recommendation}

Increase in Salary, Better infrastructure in health facilities, Reservation in PG seats, Increase emphasis on community-based medical education in all medical colleges. Extended clinical training in rural health facilities and long-term community engagement during MBBS teaching and establishment of Medical colleges in rural or remote areas are the interventions which can work in improving the current deficit of doctor in rural health posts as well as change in the attitude and perception of young medical graduate towards rural health services.

\section{Conflict of Interest: None.}

\section{References}

1. Chen L, Evans T, Anand S, Boufford JI, Brown H. Human resources for health: overcoming the crisis. Lancet 2004;364:1984-90

2. Deo MG. Doctor population ratio for India - The reality. Indian J Med Res 2013;137:632-5.

3. Medical Council of India. Available from: http://www.mciindia.org/apps/search/show_colleges.asp. [Last accessed on 2015 Aug 15].

4. Government of India. Bulletin on Rural Health Statistics 20122013. Ministry of Health and Family Welfare, National Rural Health Mission. New Delhi: Government of India; 2013

5. Dussault G, Franceschini MC. Not enough there, too many here: Understanding geographical imbalances in the distribution of the health workforce. Hum Resour Health 2006;4:12.

6. Lehmann U, Dieleman M, Martineau T. Staffing remote rural areas in middle and low-income countries: A literature review of attraction and retention. BMC Health Serv Res 2008;8:19.

7. Rao KD, Bhatnagar A, Berman P. So many, yet few: Human resources for health in India. Hum Resour Health 2012;10:19.

8. Mudur G. India decides to train non-medical rural healthcare providers. BMJ 2010;340:c817.
9. Rao KD, Gupta G, Jain K, Bhatnagar A, Sundararaman T, Which doctor for primary health care? An Assessment of primary health care providers in Chhattisgarh, India. New Delhi: Public Health Foundation of India, 2010.

10. Saini NK, Sharma R, Roy R, Verma R. What impedes working in rural areas? A study of aspiring doctors in the National Capital Region, India. Rural Remote Health 2012;12:1967.

11. Jain M, Gupta SA, Gupta AK, Roy P. Attitude of would-be medical graduates toward rural health services: An assessment from Government Medical Colleges in Chhattisgarh. J Family Med Prim Care 2016;5:440-3

12. Choudhary Y, Dubey M, Toppo M, Pal DK. Perception of medical students towards serving rural people: A study from central India. Int J Community Med Public Health 2018;5:1580-3.

13. Ossai EN, Anyanwagu UC, Azuogu BN, Uwakwe KA, Ekeke $\mathrm{N}$, Perception about Working in Rural Area after Graduation and Associated Factors: A Study among Final Year Medical Students in Medical Schools of Southeast Nigeria.

14. Wandira G, Maniple E. Do Ugandan medical students intend to work in rural health facilities after training? Health Policy Dev 2009;7:203-14

15. Curran VR, Fleet L, Pong RW, Bornstein S, Jong M, A survey of rural medical education strategies throughout the medical education continuum in Canada. Cah Sociol Demogr Med 2007;47:445-68.

16. Wilson NW, Couper ID, De Vries E, Reid S, Fish T, Marais BJ.A critical review of interventions to redress the inequitable distribution of healthcare professionals to rural and remote areas. Rural Remote Health 9: 1060. (Online) 2009. Available: www.rrh. org.au (Accessed 16 January 2012).

17. Zaidi SA. Why medical students will not practice in rural areas: Evidence from a survey. Soc Sci Med 1986;22:527-33.

18. Shankar PR. Attracting and retaining doctors in rural Nepal. Rural Remote Health 2010;10:1420.

19. Bundred PE, Levitt C. Medical migration: Who are the real losers? Lancet 2000;356:245-6.

20. Mudur G. India seeks to pay extra to attract doctors into villages, but health workers are sceptical. $\mathrm{Br} \mathrm{Med} \mathrm{J}$ 2009;339:2781.

How to cite this article: Gupta D, Yadav SK, Piyush AR, Gupta NM, Nath B. Assessment of attitude and perception of medical students towards rural health services in hilly region of Uttarakhand. Indian J Forensic Community Med 2019;6(1):55-60. 